\title{
Energy piles: current state of knowledge and design challenges
}

DOI:

doi.org/10.1680/ENVGEO.13.00019

\section{Document Version}

Final published version

Link to publication record in Manchester Research Explorer

\section{Citation for published version (APA):}

Abuel-Naga, H., Raouf, A. M. I., Raouf, M. I. N., \& Nasser, A. (2015). Energy piles: current state of knowledge and design challenges. Environmental Geotechnics, 2(EG4), 195-210.

https://doi.org/doi.org/10.1680/ENVGEO.13.00019

\section{Published in:}

Environmental Geotechnics

\section{Citing this paper}

Please note that where the full-text provided on Manchester Research Explorer is the Author Accepted Manuscript or Proof version this may differ from the final Published version. If citing, it is advised that you check and use the publisher's definitive version.

\section{General rights}

Copyright and moral rights for the publications made accessible in the Research Explorer are retained by the authors and/or other copyright owners and it is a condition of accessing publications that users recognise and abide by the legal requirements associated with these rights.

\section{Takedown policy}

If you believe that this document breaches copyright please refer to the University of Manchester's Takedown Procedures [http://man.ac.uk/04Y6Bo] or contact uml.scholarlycommunications@manchester.ac.uk providing relevant details, so we can investigate your claim.

\section{OPEN ACCESS}




\section{Energy piles: current state of knowledge and design challenges}

Hossam Abuel-Naga MSc, PhD

Senior Lecturer, Department of Civil and Environmental Engineering, The University of Auckland, Auckland, New Zealand

Mohammad Imad N. Raouf MSc, PhD

Senior Engineer, Research and Development Committee, Qatar General Electricity and Water Corporation KAHRAMAA, Doha, Qatar
Ayman M.I. Raouf BE (Hons)

Postgraduate Student, Bogazici University, Istanbul, Turkey

Adel G. Nasser MSc, PhD

Senior Project Manager, School of Mechanical, Aerospace and Civil

Engineering, The University of Manchester, Manchester, UK

Energy piles offer a promising and eco-friendly technique to heat or cool buildings. Energy piles can be exploited as ground heat exchangers of a ground source heat pump system. In such application, the energy pile and its surrounding soil are subjected to temperature changes that could significantly affect the pile-soil interaction behaviour. The aim of this paper is to review the current state of knowledge on the design of energy piles in terms of the geostructural and heat exchanger functions. Furthermore, a conceptual understanding of the potential temperature effects on the mechanical behaviour of piles is proposed in this paper. Based on this conceptual understanding as well as the reported thermo-hydro-mechanical behaviour of saturated clays in the literature, the challenging geotechnical aspects facing the energy pile design are highlighted, and further research efforts to refine them are recommended.

\section{Introduction}

The expected increase in population and living standards worldwide is intensifying the search for energy sources. As fossil fuels are a non-renewable energy source, and burning them contributes to the greenhouse effect, there is an urgent need to find alternative, renewable and sustainable ways of generating energy. One of the promising techniques in the renewable energy field that can be used to cool/heat buildings is the heat pump (HP) system. Unlike the vast majority of wind and solar power generation sources, HP systems could be readily employed almost anywhere. Although HPs are powered by electricity, they supply more heating/cooling at a more efficient cost and, more importantly, at a reduced greenhouse effect than direct electric methods. In principle, HPs use electricity to transfer heat from one place to another instead of using electricity to create heat, and therein lies their advantage. The heat transfer process is done by a refrigeration cycle in the HP that comprises five components: compressor, condenser, expansion device, refrigerant and evaporator.

The ground source heat pump (GSHP) is a type of HP that pumps heat from or to the earth using a coil placed within the earth at depths of $5 \mathrm{~m}$ or more below the ground surface level, where temperatures are relatively stable regardless of the outside ambient air temperature. This constant temperature can be used as a heat sink/source. In the heating mode, the HP extracts heat from the earth and pumps it via a refrigeration cycle to the building. In the cooling mode, the reverse occurs, where heat is extracted from the interior of the building and rejected to the earth.

Brandl (2006) discussed in detail the feasibility of incorporating a ground heat exchanger system within deep building foundations (piles) buried under the ground. This method has broad appeal because concrete is an ideal medium as a heat absorber in the ground owing to its good thermal conductivity and thermal storage capacity (Brandl, 2006). These new piles could be called "energy piles" or "thermo-piles" and can be described as dual-purpose structure elements since they utilise the required ground-concrete contact element that is constructed for structural reasons as a heat exchanger unit. The energy pile concept can be considered as a notable progress in the GSHP domain since it can reduce the initial cost of drilling boreholes and the land area required for borehole installation. Creating an energy pile is a relatively simple process that involves introducing U-tube pipe-works around the surface of a cast-in-place concrete pile, as shown in Figure 1. Each flexible plastic loop (generally one tube down and the return tube back up) is fitted into the pile reinforcement cages. The U-tubes are usually $3 / 4$ or 1 inch $(27$ or $34 \mathrm{~mm})$ in diameter.

Although the energy pile concept has been used successfully in some countries such as the UK (Knellwolf et al., 2011), Austria (Brandl, 2006) and Germany (Ennigkeit and Katzenbach, 2001), other countries are reluctant to accept this technique mainly due to concerns regarding the potential impact of temperature cycles on the structural performance of the pile (load capacity and settlement issues), as shown in Figure 2. The energy pile differs from the conventional pile as it is subjected to mechanical and thermal loads. This coupled loading condition highlights the need to have a clear understanding of temperature effects on the mechanical behaviour of soils as well as the pile-soil interaction.

In the following sections, a conceptual understanding of temperature effects on pile-soil interaction will be proposed. Then, a critical review will be presented of the current understanding of the thermo-mechanical behaviour of saturated clays and the 


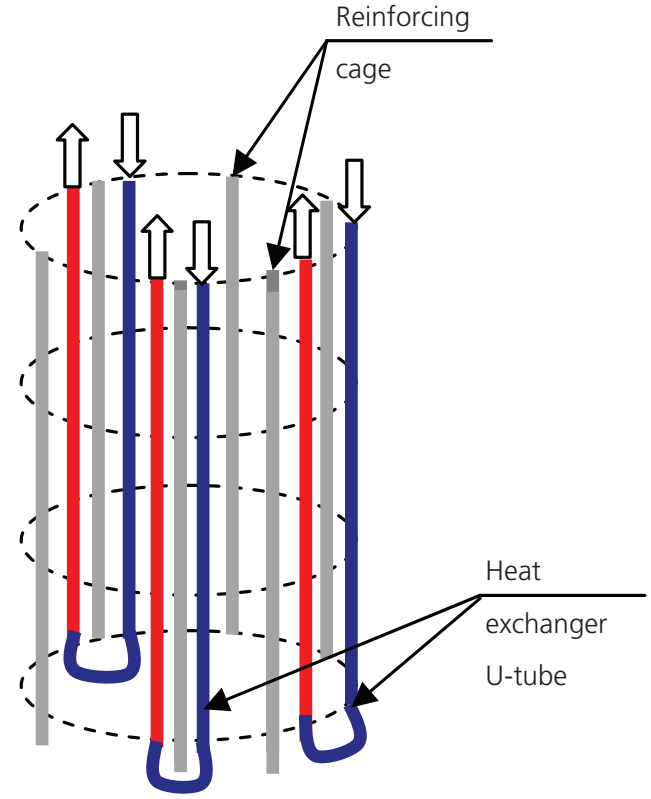

Figure 1. Energy pile

available energy pile design approach in the literature. Finally, the energy pile heat exchanger function will be discussed in terms of the thermal conductivity of soils, as this has a significant effect on the heat exchange capacity of the energy pile.

\section{Potential temperature effects on pile-soil interaction}

During the heating and cooling cycles, the energy pile and its surrounding soil would expand or contract and in turn will affect the pile-soil interaction. In some cases, unwanted consequences may arise, such as additional building settlement, tensile axial stresses, large compressive axial stresses or mobilisation of a limited resistance on the pile shaft. The possible temperature effects on the pile behaviour can be conceptualised as shown in Figure 3, where the equilibrium of a pile shaft element and its surrounding soil is presented under only mechanical load and under the combination of mechanical and thermal loads. In the axial direction of the energy pile (Figure $3 \mathrm{~b}$ ), the thermally induced axial pile stress $P^{\mathrm{T}}$ is a function of thermal expansion coefficient and elastic modulus of concrete as well as the pile restrained condition (Bourne-Webb et $a l ., 2012)$. The thermally mobilised interface shear stress change at the soil-pile interface $\mathrm{d} P S / \mathrm{d} T$ depends on the differential thermally induced axial strain between the pile and the surrounding soil, the temperature effect on the interface shear coefficient and the radial confinement effective stress $\mathrm{Pr}$ and its thermal evolution $\mathrm{d} P \mathrm{P} /$ $\mathrm{d} T$. In fact, $\mathrm{d} P r / \mathrm{d} T$ depends on the differential thermally induced radial strain between the pile and the surrounding soil, the effect of temperature on the lateral earth pressure coefficient of soil and the thermally induced pore water pressure. In addition, $\mathrm{d} P r / \mathrm{d} T$ and $\mathrm{d} P S /$ $\mathrm{d} T$ could also be functions of cyclic heating and cooling properties.
Based on the above conceptual understanding of the temperature effects on pile structural behaviour, it can be concluded that the design of an energy pile should be conducted using a coupled thermo-hydromechanical soil-structure interaction model that is able to predict $\mathrm{d} P r / \mathrm{d} T$ and $\mathrm{d} P S / \mathrm{d} T$ and the corresponding strains. Therefore, the proper design of an efficient energy pile should involve (i) thorough understanding of the thermo-mechanical properties of soils and (ii) use of a special design approach that considers the structural function of the pile under cyclic temperature conditions.

\section{Thermo-mechanical behaviour of saturated clays}

\section{Thermally induced volume change}

Previous studies in the literature have conclusively shown that the volumetric change of saturated fine-grained soils subjected to temperatures less than the boiling point of water $\left(100^{\circ} \mathrm{C}\right)$ depends on the stress history (Baldi et al., 1988; Burghignoli et al., 2000; Cekerevac and Laloui, 2004; Del Olmo et al., 1996; Delage et al., 2000; Graham et al., 2001; Kuntiwattanakul et al., 1995; Laloui and Cekerevac, 2003; Towhata et al., 1993). In terms of volumetric strains, the normally consolidated clays contract irreversibly and non-linearly upon heating, whereas the highly overconsolidated clays exhibit reversible expansion, as shown in Figure 4 for soft Bangkok clay. The effect of the stress history on the thermally induced volume change of different clays under different elevated temperature changes $\Delta T$ is depicted in Figure 5 . It can be seen that as the overconsolidation ratio (OCR) increases, the magnitude of the thermally induced contracted volumetric strain initially decreases, and the clay then gradually starts to show a dilative behaviour beyond a certain OCR value.

Many researchers attributed the observed thermally induced volume change behaviour of saturated clays to temperature effects on physico-chemical interactions between clay particles, which depend essentially on the clay lattice constitution, the chemical nature of the interstitial fluid and the interlayer distance (Laloui and Cekerevac, 2003; Robinet et al., 1996). As the soil plasticity index $P I$ could give a qualitative indication of the physico-chemical interactions of clays, PI could affect the magnitude of thermally induced volumetric strain. Figure 6 shows the relationship between the temperature-induced volumetric strains of different types of normally consolidated clay under $\Delta T \approx 65^{\circ} \mathrm{C}$ to $70^{\circ} \mathrm{C}$ and their PIs. The results show a reasonably linear trend between the thermally induced volume change and the PI.

\section{Effects of temperature on preconsolidation pressure and} the normal compression line

The previous experimental results reported by Eriksson (1989), Boudali et al. (1994) and Moritz (1995) show a decrease in preconsolidation pressure with increasing temperature up to $25^{\circ} \mathrm{C}$. However, above this temperature level $\left(25^{\circ} \mathrm{C}\right)$, the preconsolidation pressure is approximately constant and independent of temperature, as shown in Figure 7. Furthermore, earlier experimental results by 


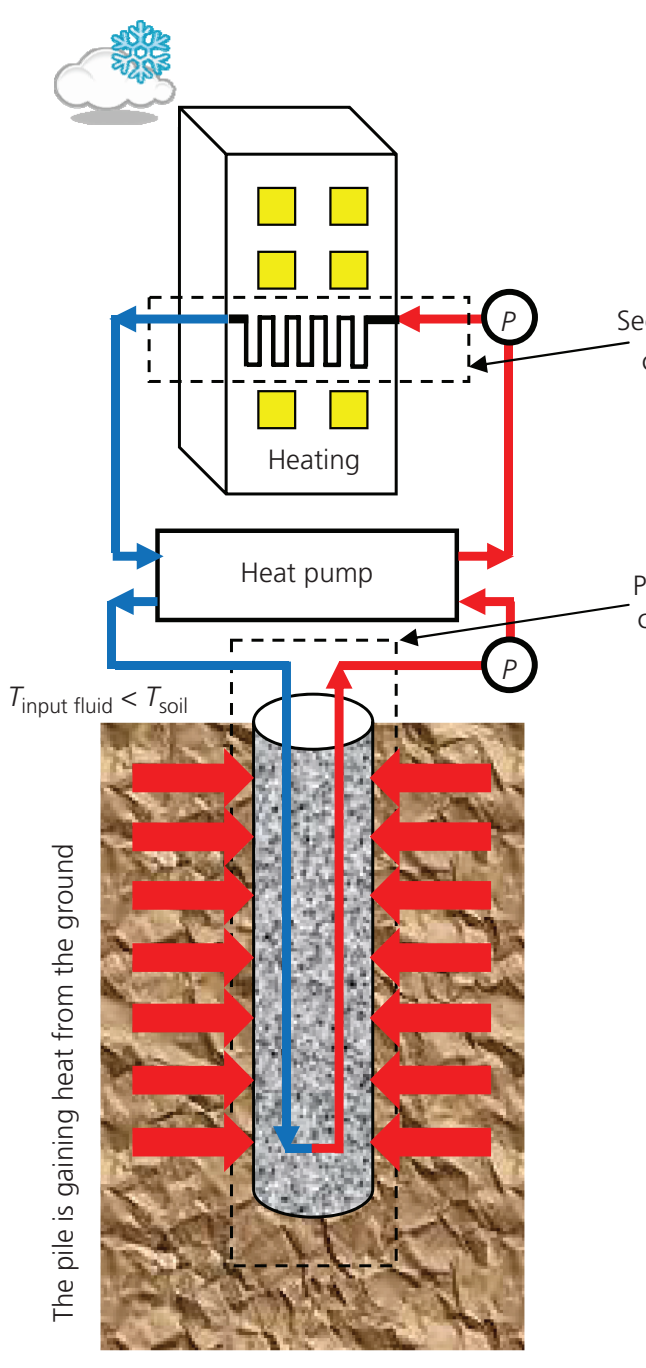

Winter operation

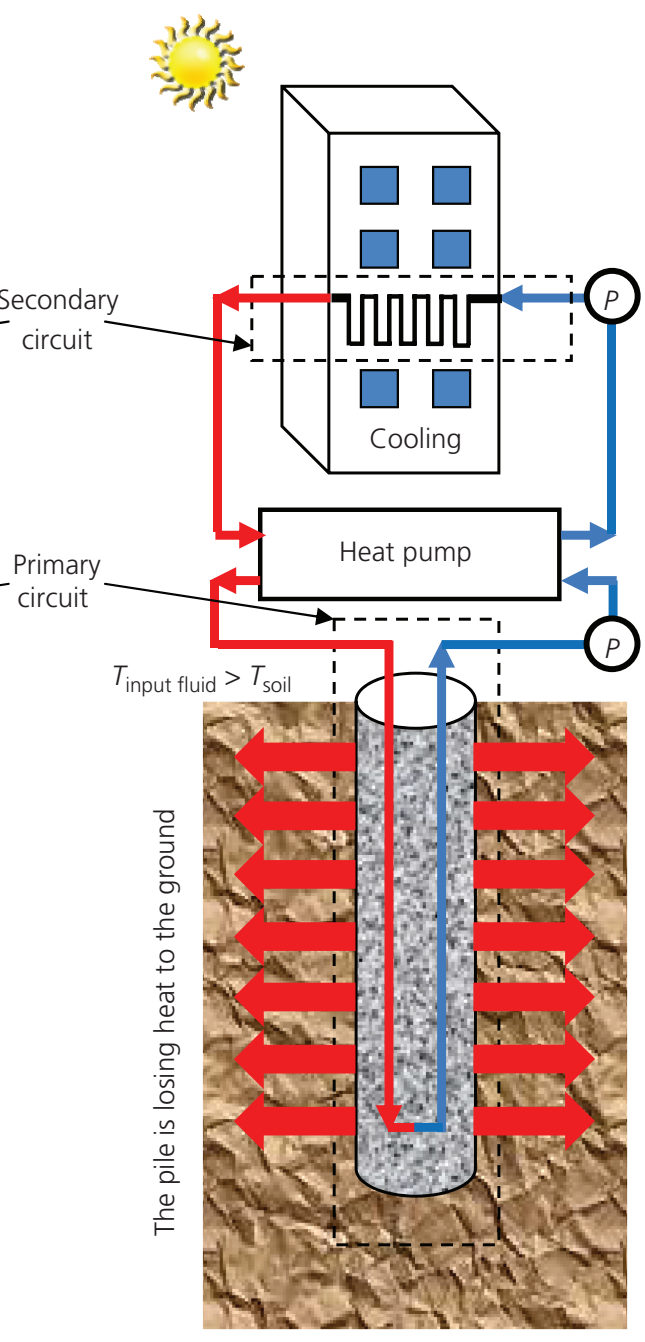

Summer operation

Figure 2. Energy pile heat exchanger behaviour during the winter and summer operations

Hueckel and Baldi (1990) and Robinet et al. (1996) on reconstituted Pontida silty clay and Boom clay respectively show that subjecting the normally consolidated clay to heating/cooling cycles induces an apparent overconsolidation state at constant plastic strain conditions. Consequently, further loading under elastic stiffness conditions is required to reach again the yielding mode. Along the same lines, the preconsolidation pressure of soft Bangkok clay shows a temperature independency during the heating phase from $25^{\circ} \mathrm{C}$ to $90^{\circ} \mathrm{C}$, as shown in Figure 8 . Furthermore, soft Bangkok clay shows an apparent overconsolidation state after being subjected to a heating/cooling phase, as shown in Figure 9. Previous research works also show that the compression line moves to the left as the soil temperature increases, with a similar slope, causing a reduction in the elastic domain at constant plastic strain (Campanella and Mitchell, 1968; Graham et al., 2001; Hueckel and Baldi, 1990; Laloui and Cekerevac, 2003). A similar behaviour was observed for soft Bangkok clay, as shown in Figure 8.
Effect of temperature on shear strength

Graham et al. (2001) studied the undrained shear strength of normally consolidated remoulded illitic clay specimens at different temperature levels $\left(28^{\circ} \mathrm{C}, 65^{\circ} \mathrm{C}\right.$ and $\left.100^{\circ} \mathrm{C}\right)$. The specimens were subjected to drained heating before shearing under undrained conditions at elevated temperature. The results showed that the shear strength increased as the temperature increased, as shown in Figure 10. A similar observation was reported by Kuntiwattanakul et al. (1995) for reconstituted MC clay specimens tested at room temperature $\left(20^{\circ} \mathrm{C}\right)$ and elevated temperature of $90^{\circ} \mathrm{C}$, as shown in Figure 11. Abuel-Naga et al. (2006b, 2007b) investigated experimentally the effect of temperature on the undrained triaxial compression shear strength behaviour of normally consolidated soft Bangkok clay specimens at different temperature levels and histories. The temperature histories related to specimens being subjected to heating/cooling cycles before conducting the shear testing. The test results indicated that the undrained shear strength and secant 


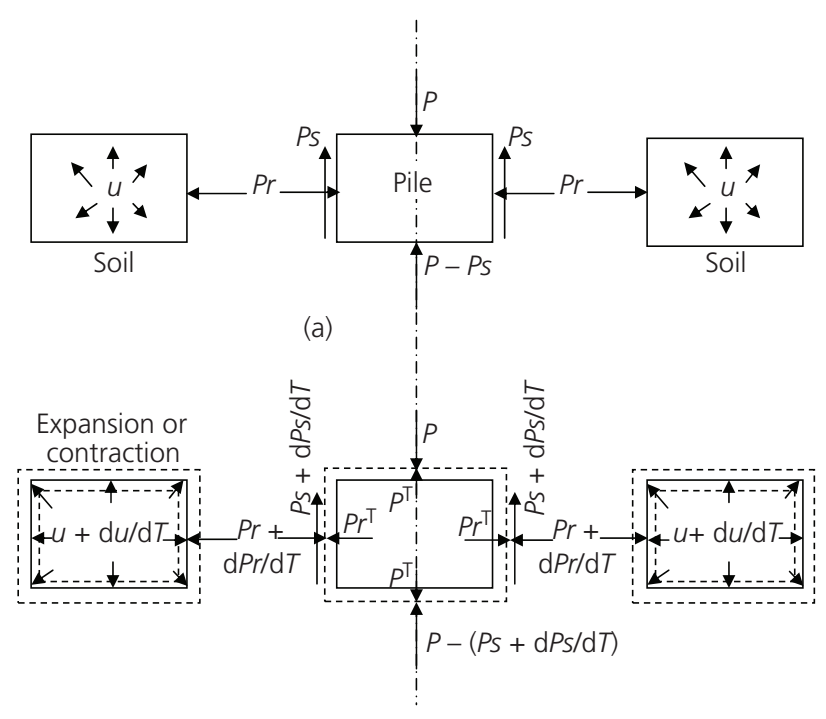

(b)

$P$ : axial pile stress

Pr: radial confinement stress

Ps: pile shaft resistance

$P^{T}$ : thermally induced axial pile stress

$\mathrm{Pr}^{\top}$ : thermally induced radial pile stress

$u$ : pore water pressure

$T$ : temperature

Element boundary under mechanical load

Element boundary under mechanical and thermal load

Figure 3. Conceptual equilibrium of a pile shaft element: (a) mechanical load; (b) mechanical and thermal load

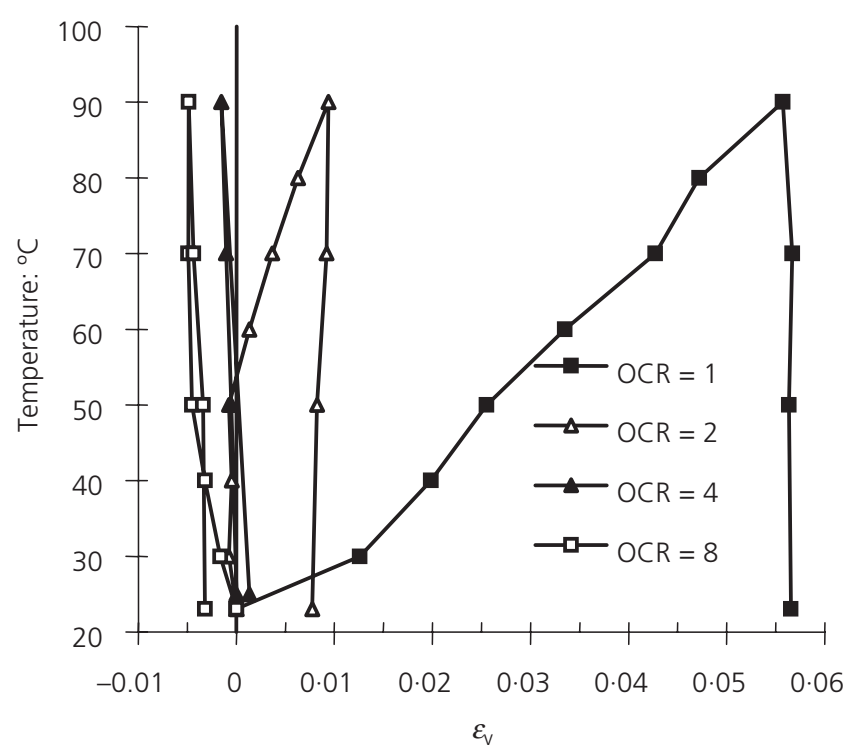

Figure 4. Soft Bangkok clay temperature volumetric strain under drained heating/cooling cycle at different OCR values, preconsolidation pressure $=200 \mathrm{kPa}$ (Abuel-Naga et al., 2006b)

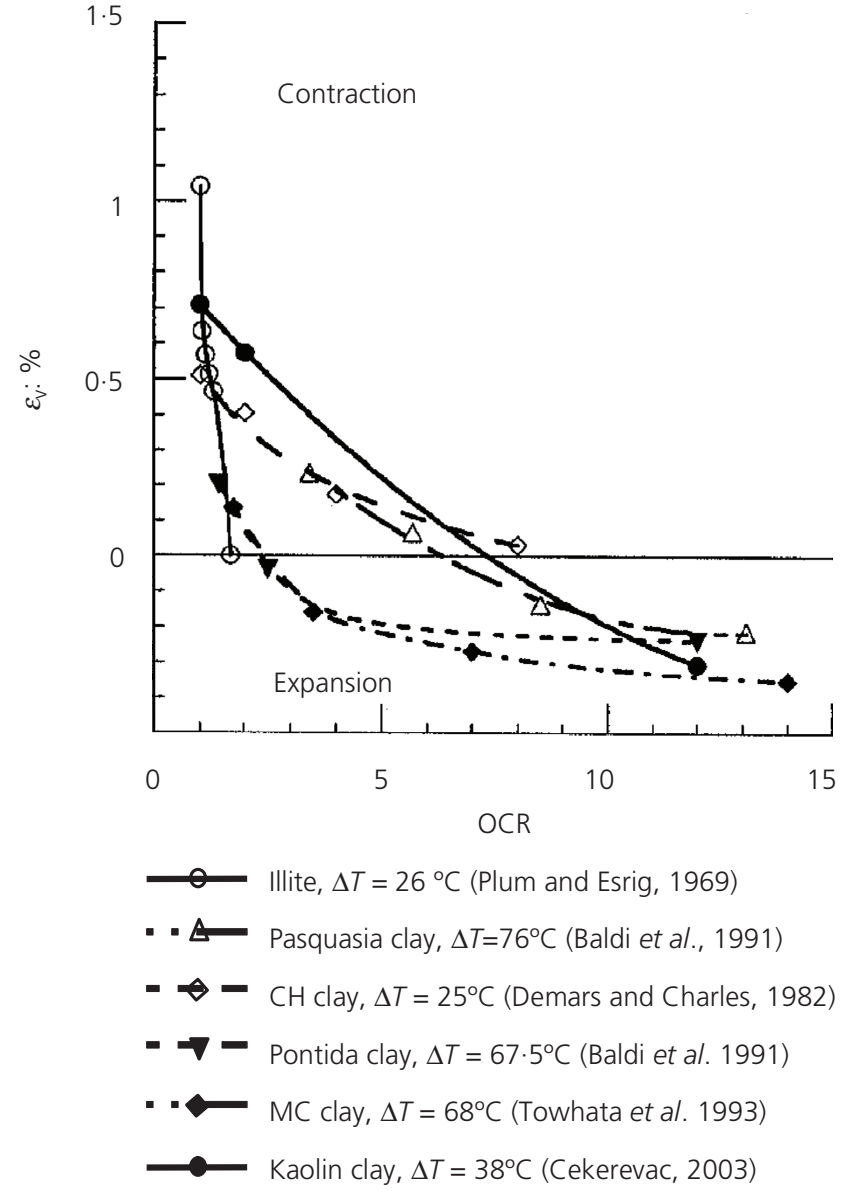

Figure 5. Effect of OCR on the temperature-induced volume change for different types of clay from literature (Abuel-Naga et al., 2007c)

modulus of the normally consolidated clay increases as the soil temperature increases or after subjecting it to temperature cycling, as shown in Figure 12. Abuel-Naga et al. (2007c, 2009) proposed a robust constitutive model for predicting the temperature effects on saturated clays. The model predictions for the different types of clay are shown in Figures 10, 11, and 13. Reasonable agreement can be observed between the test results and the model predictions.

\section{Effect of temperature on the hydraulic conductivity}

Many researchers have studied the effect of temperature on the coefficient of hydraulic conductivity (Burghignoli et al., 2000; Delage et al., 2000; Habibagahi, 1977; Houston and Lin, 1987; Morinl and Silva, 1984; Towhata et al., 1993). In general, all of these studies reported that the hydraulic conductivity of the soil increases as the temperature increases. However, some of these studies used direct methods such as the constant head method (Delage et al., 2000; Morin and Silva, 1984). On the other hand, some of these studies used the indirect method, which employs the coefficient of consolidation measurements obtained from isothermal consolidation tests performed at various temperatures (Habibagahi, 1977; Towhata 


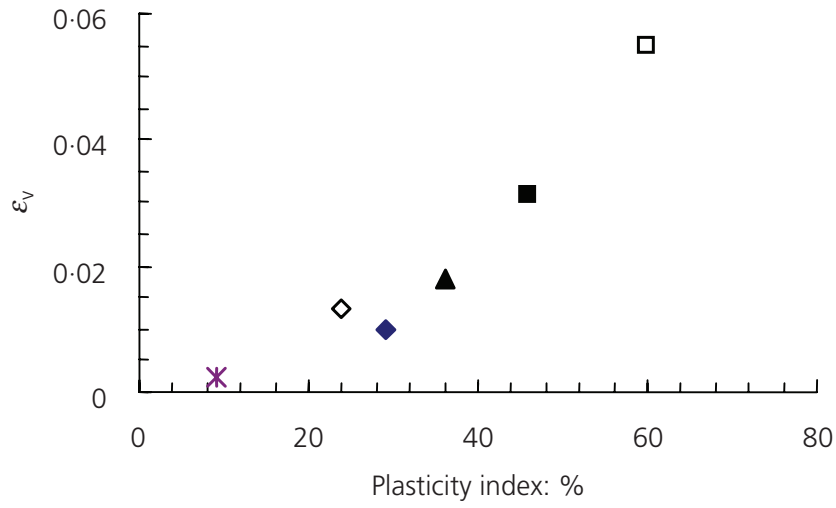

- MC clay, PI = 29\% (Towhata et al., 1993)

Boom clay, PI = 46\% (Sultan et al., 2002)

口 Soft Bangkok clay, PI = 60\% (Abuel-Naga et al., 2006b)

* Illite, PI = 9\% (Graham et al., 2001)

$\Delta$ Boom clay, $\mathrm{Pl}=36 \%$ (Baldi et al., 1991)

$\diamond \mathrm{MC}$ clay, PI = 24\% (Laloui and Cekerevac, 2003)

Figure 6. Relationship between plasticity index of soil and temperature-induced volumetric strain of different normally consolidated clays, where $\Delta T \approx 65-70^{\circ} \mathrm{C}$, and $T_{0} \approx 20-25^{\circ} \mathrm{C}$ (Abuel-Naga et al., 2007c)

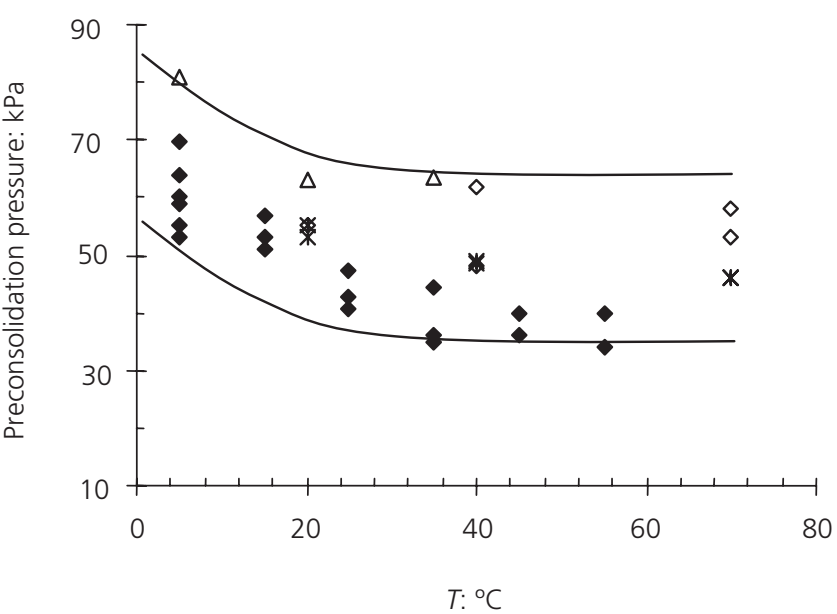

- Lulea clay (Eriksson, 1989)

$\Delta$ Berthierville clay (Boudali et al., 1994)

* Natural Swedish clay, 6.0 m depth (Moritz, 1995)

$\diamond$ Natural Swedish clay, 9.0 m depth (Moritz, 1995)

Figure 7. Temperature effect on preconsolidation pressure (AbuelNaga et al., 2007c)

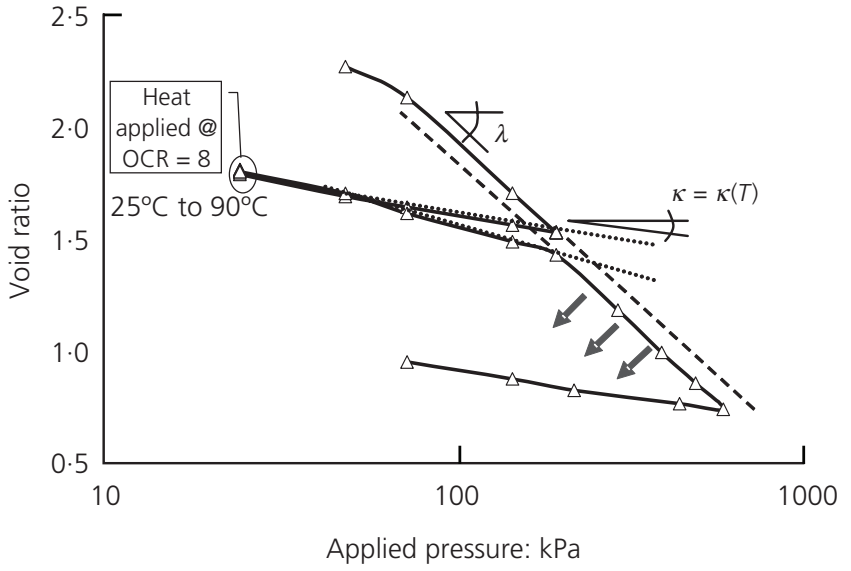

Figure 8. Consolidation curve of soft Bangkok clay at different temperatures (Trani et al., 2010)

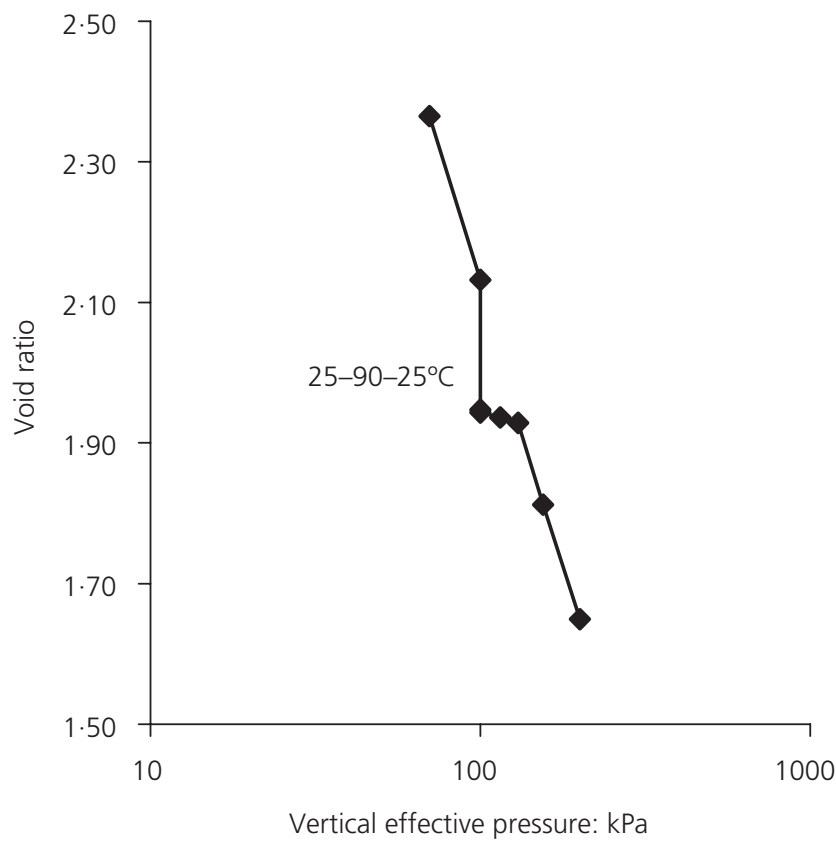

Figure 9. Temperature-induced overconsolidation state of normally consolidated soft Bangkok clay after drained heating/ cooling cycle (Abuel-Naga et al., 2006b)

et al., 1993). As Terzaghi theory has a series of assumptions that do not properly fit the actual behaviour of natural clays, the indirect method should not be used for determining the hydraulic conductivity (Tavenas et al., 1983). Delage et al. (2000) observed that the hydraulic conductivity values estimated by the indirect method are higher than the hydraulic conductivity estimated using direct methods by a factor of about four in the case of Boom clay. The effect of temperature up to $90^{\circ} \mathrm{C}$ on the hydraulic conductivity of soft Bangkok clay was investigated by Abuel-Naga et al. (2006b) using a flexible wall permeameter. The results indicated that as 

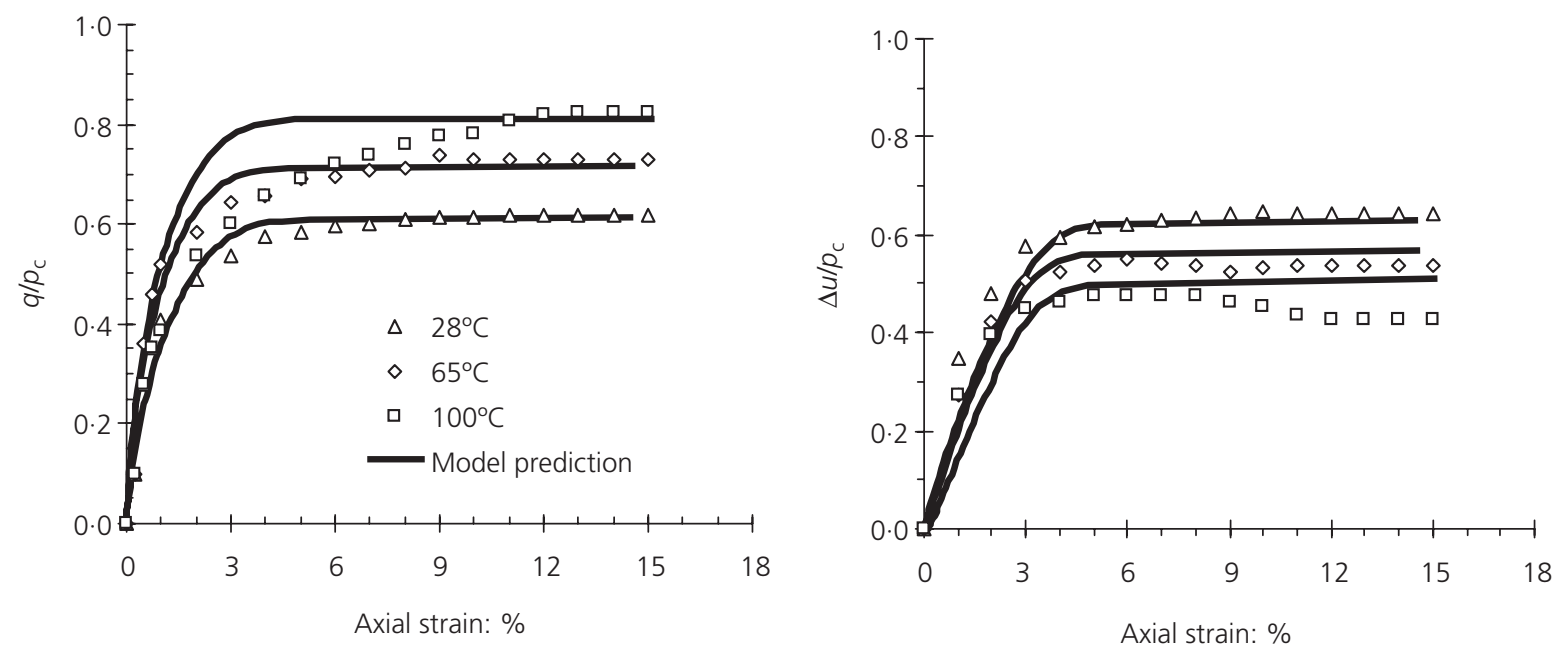

Figure 10. Comparison between the proposed model prediction (Abuel-Naga et al., 2009b) and the compression triaxial test results of normally consolidated $\mathrm{MC}$ clay specimen at different temperature levels $p_{c}=1500 \mathrm{kPa}$ (Graham et al., 2001)
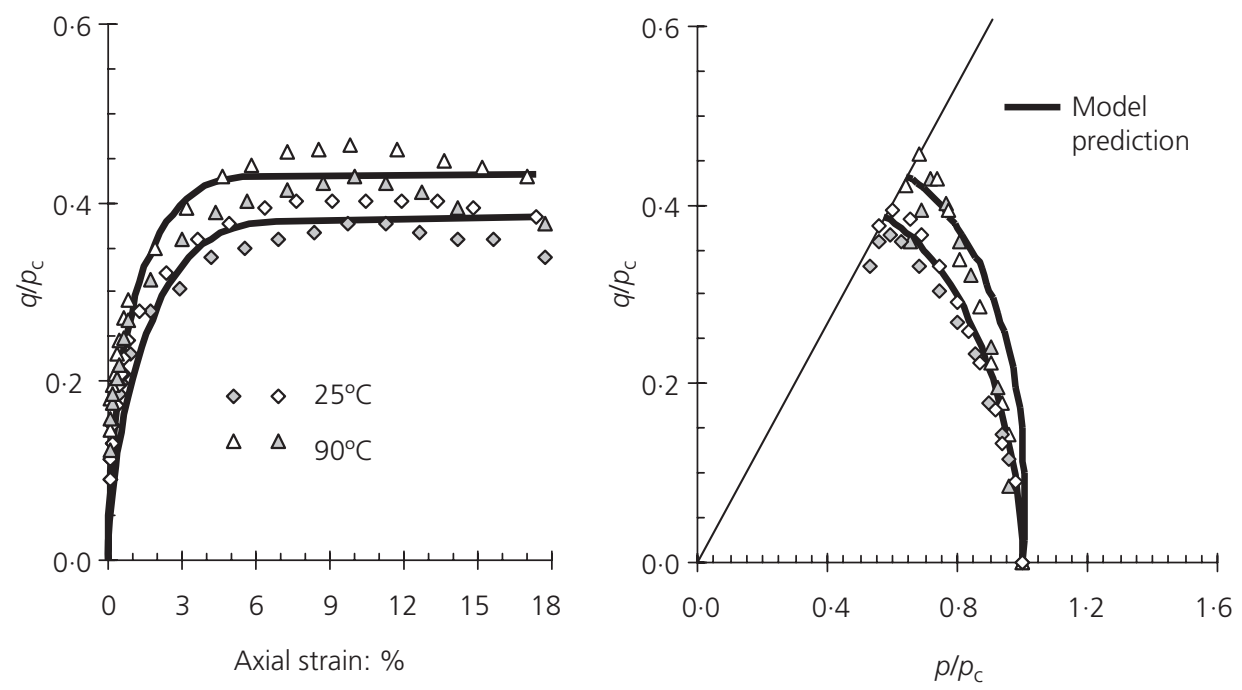

Figure 11. Comparison between the proposed model prediction (Abuel-Naga et al., 2009b) and the compression triaxial test results of normally consolidated $\mathrm{MC}$ clay specimen at different temperature levels $p_{c}=196 \mathrm{kPa}$ (Kuntiwattanakul et al., 1995)

the soil temperature increased, the hydraulic conductivity also increased, as shown in Figure 14. This behaviour was attributed to the thermal evolution of the pore soil liquid viscosity.

\section{Thermally induced pore water pressure}

Heating a saturated clay specimen under undrained conditions and constant total stresses increases its volume and pore water pressure due to the difference between the thermal expansion coefficient of water and solid particles. Experimental results reported by Hueckel and Pellegrini (1992) show that heating an isotropic consolidated clay specimen that is subjected to shear stress up to a certain limit (less than the shear strength) generates a thermally induced pore water pressure that could initiate failure if the stress state approaches the strength envelop.

Campanella and Mitchell (1968) expressed the thermally induced pore water pressure in terms of the thermal expansion and compressibility of the soil components as follows: 

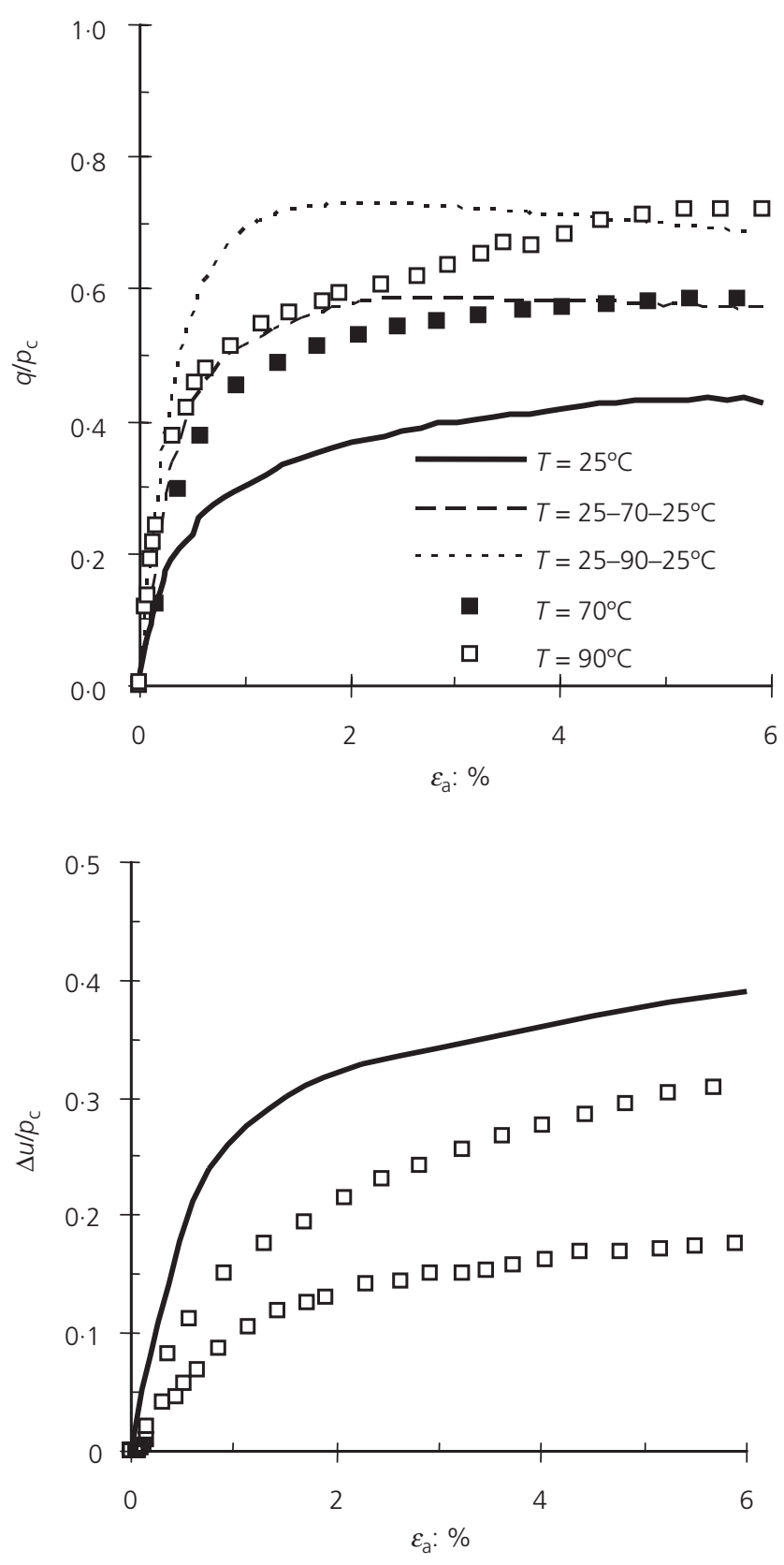

Figure 12. Undrained triaxial compression test results of normally consolidated soil tested at different temperatures or after subjecting to different heating/cooling cycles (Abuel-Naga et al., 2006)

1. $\Delta u=\frac{n \Delta T\left(\alpha_{\mathrm{s}}-\alpha_{\mathrm{w}}\right)+\alpha_{\mathrm{st}} \Delta T}{m_{\mathrm{v}}+n m_{\mathrm{w}}}$

where $n$ is the porosity, $\alpha_{\text {st }}$ is the physicochemical temperature coefficient of the soil structure volume change, $m_{\mathrm{v}}$ is the compressibility of the soil structure, $m_{\mathrm{w}}$ is the compressibility of water, $\alpha_{\mathrm{s}}$ is the thermal coefficient of cubical expansion of mineral solids and $\alpha_{\mathrm{w}}$ is the thermal coefficient of expansion of soil water.

However, the above form has some limitations due to the difficulties in evaluating $\alpha_{\mathrm{st}}, \alpha_{\mathrm{s}}$ and $\alpha_{\mathrm{w}}$. Houston et al. (1985), Tanaka et al. (1997) and Abuel-Naga et al. (2007b) investigated experimentally the effect of stress level and history on the thermally induced pore water pressure. Their results show that $(i)$ the rate of the thermally induced pore water pressure increase with temperature is nonlinear, (ii) a higher consolidation pressure produces a larger pore water pressure increase for a given temperature increase, (iii) the rate of increase in the thermally induced pore water pressure is stress history dependent (OCR) and tends to decrease as the OCR increases and (iv) the thermally induced pore water pressure of the normally consolidated specimens was reversible whereas the overconsolidated specimens showed an irreversible behaviour.

\section{Geostructural behaviour of energy piles}

There is little published quantitative evidence in the public domain regarding the geostructural performance of the energy pile. Only three studies have been identified: one in Austria (Brandl, 1998), one in Switzerland (Laloui et al., 2006) and one in the UK (Bourne-Webb et al., 2009). The authors are aware of some other tests carried out in Australia and the US, but the results of these tests have not been published yet. The three published cases, while providing useful insights into the behaviour of these systems, have shortcomings, such as presenting incomplete information and not being representative of an operational system or being of short duration (Bourne-Webb et al., 2012). The results of these in situ experiences show that application of a thermal load induces a significant change in the structural behaviour of a foundation pile (Amis et al., 2008; Bourne-Webb et al., 2009; Laloui et al., 2006). In general, the previous studies showed that heating of a pile induces an additional compression stress in the pile and increases the mobilised shear stress. However, cooling can induce a release of the mobilised shear stress, possibly leading to the reversal of shear stress signs and the development of tensile stress in the pile. It should also be mentioned that the ground conditions, the interaction between the pile and the supported structure and the degree of axial fixity at pile toe (end restrain conditions) could significantly affect the magnitude and distribution of the thermally induced axial load in the pile (Amatya et al., 2012; Bourne-Webb et al., 2012). Figure 15 shows the axial stress response of the test pile in Switzerland (Laloui et al., 2006) with a head stress of about $1.3 \mathrm{MPa}$. The results imply that the axial stress in the pile approximately doubled with respect to the head stress during the applied thermal load, in which a temperature increase of about $15^{\circ} \mathrm{C}$ was applied.

Based on the available in situ experience, Amatya et al. (2012) and Bourne-Webb et al. (2012) proposed a simplified load transfer mechanism for a single pile subjected to pure thermal loadings (i.e. without mechanical load) and combined thermo-mechanical loadings. The proposed mechanism focused on the change in the axial stress and the mobilised shaft resistance of the energy piles in 


\section{Offprint provided courtesy of www.icevirtuallibrary.com Author copy for personal use, not for distribution}

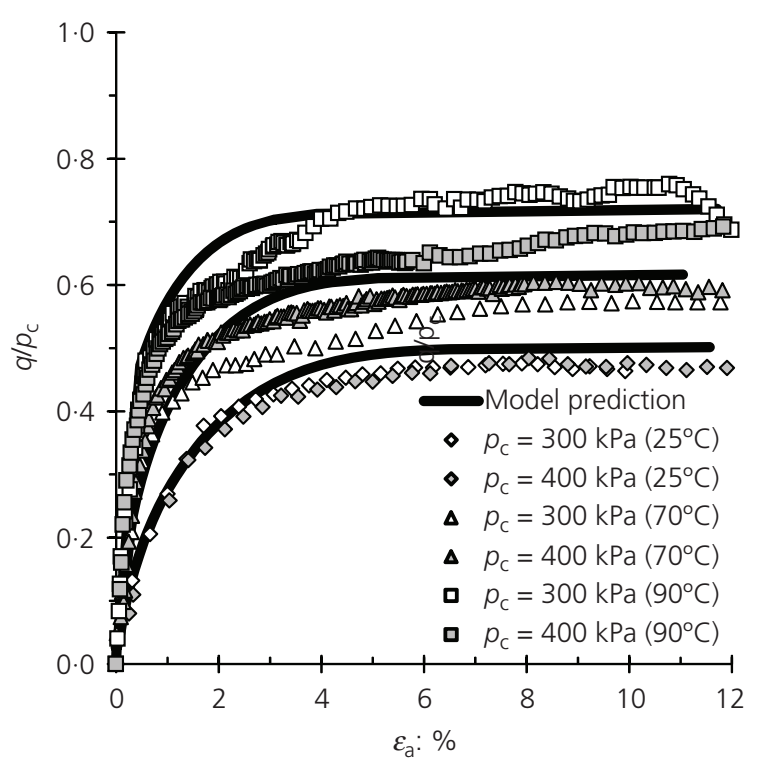

Figure 13. Comparison between the proposed model prediction (Abuel-Naga et al., 2009b) and the compression triaxial test results of normally consolidated soft Bangkok clay specimen at different temperature levels (Abuel-Naga et al., 2007b)

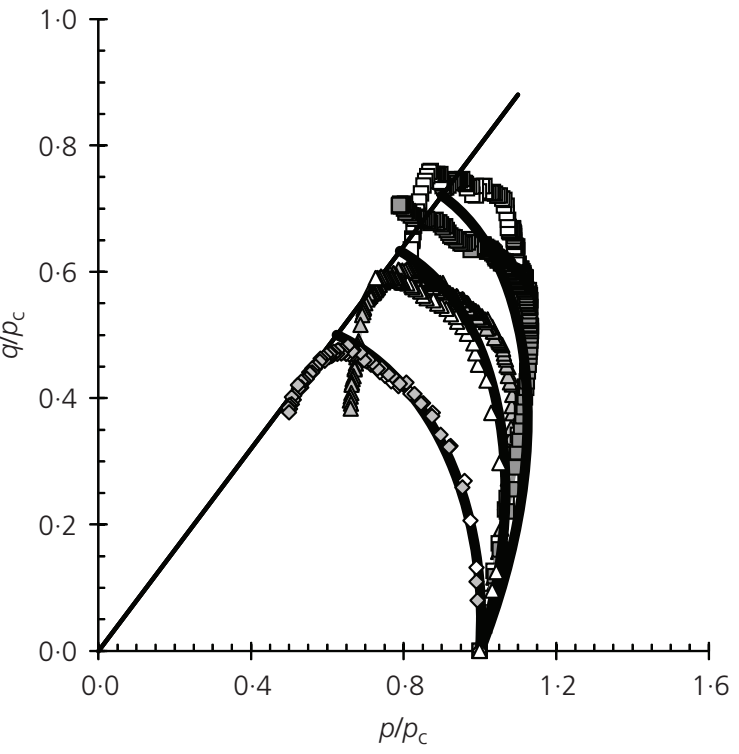

2. The properties of the pile, namely its Young's modulus and coefficient of thermal expansion, remain constant along the pile and do not change with temperature.

3. The soil and soil-pile interaction properties do not change with temperature.

The validity of these assumptions will be discussed in light of the current state of knowledge in the field of the thermo-mechanical behaviour of soils. Regarding the first assumption, considering the thermally induced axial strain of the pile and ignoring the possible thermally induced volume change of the surrounding soil could lead to error in predicting the energy pile behaviour. Several experimental studies have proven that subjecting soils to heating/ cooling cycles induces volume changes, as shown in Figures 4 and 5. Therefore, the thermally mobilised interface shear stresses at the soil-pile interface should depend on the differential thermally induced axial strain between the pile and the surrounding soils. Consequently, if the thermally induced axial strain of the pile material and the surrounding soil are identical, a special case can be found where subjecting the pile to a heating/cooling cycle will not change the axial load distribution of the pile.

The experimental results by Shoukry et al. (2011) disagree with the second assumption of Knellwolf et al. (2011), Amatya et al. (2012) and Bourne-Webb et al. (2012), as it shows that Young's modulus of concrete is temperature dependent. Furthermore, as the pile crosssection is subjected to differential temperatures due to the existence of U-tube heat exchange elements where the temperature of the in-leg is different than that of the out-leg, non-uniform thermally induced axial strain in the pile could be generated. Consequently, 


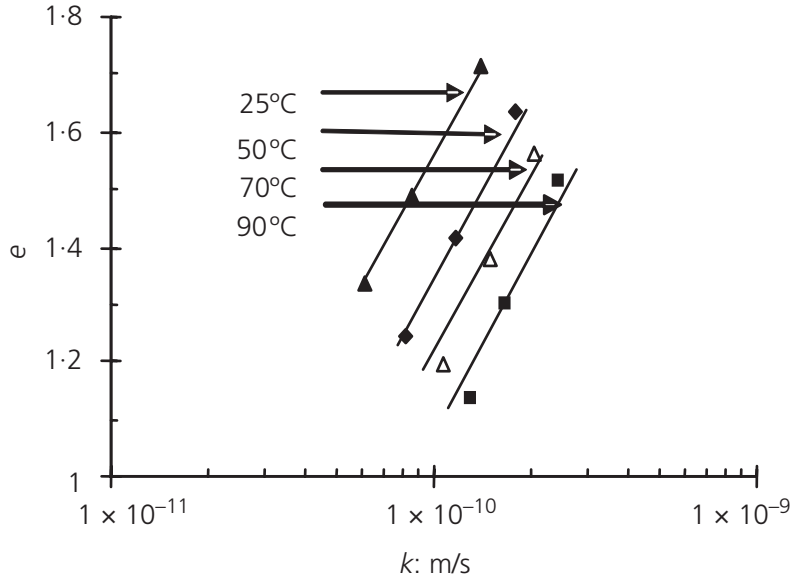

(a)

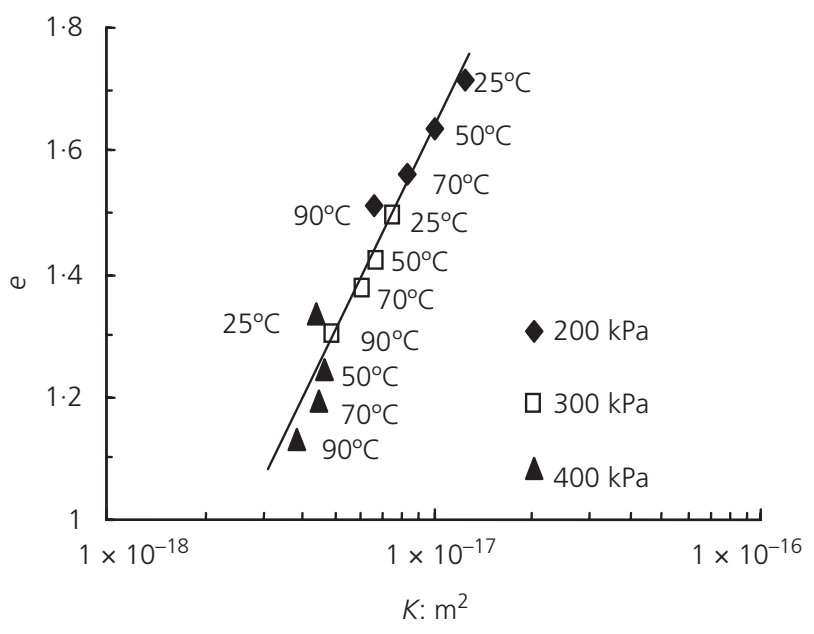

(b)

Figure 14. Effect of temperature on the hydraulic conductivity $k$ and the intrinsic permeability $K$ of soft Bangkok clay (Abuel-Naga et al., 2006b)

internal shear stress could also be developed and should be considered in the design of the pile.

With respect to assumption no. 3, several research studies (AbuelNaga et al., 2006a, 2007a, 2009; Cekerevac and Laloui, 2004; Graham et al., 2001; Kuntiwattanakul et al., 1995) have confirmed that soil engineering properties vary with temperature. Therefore, there is a possibility that the temperature may potentially affect the soil interface behaviour. However, further research is needed to confirm this point. Furthermore, ignoring the thermally induced radial strain of the pile and the surrounding soil and the thermally induced pore water pressure could also lead to misestimating the lateral confining effective stress on the shaft of the pile. Consequently, the pile shaft resistance under a heating/cooling cycle could also be miscalculated.

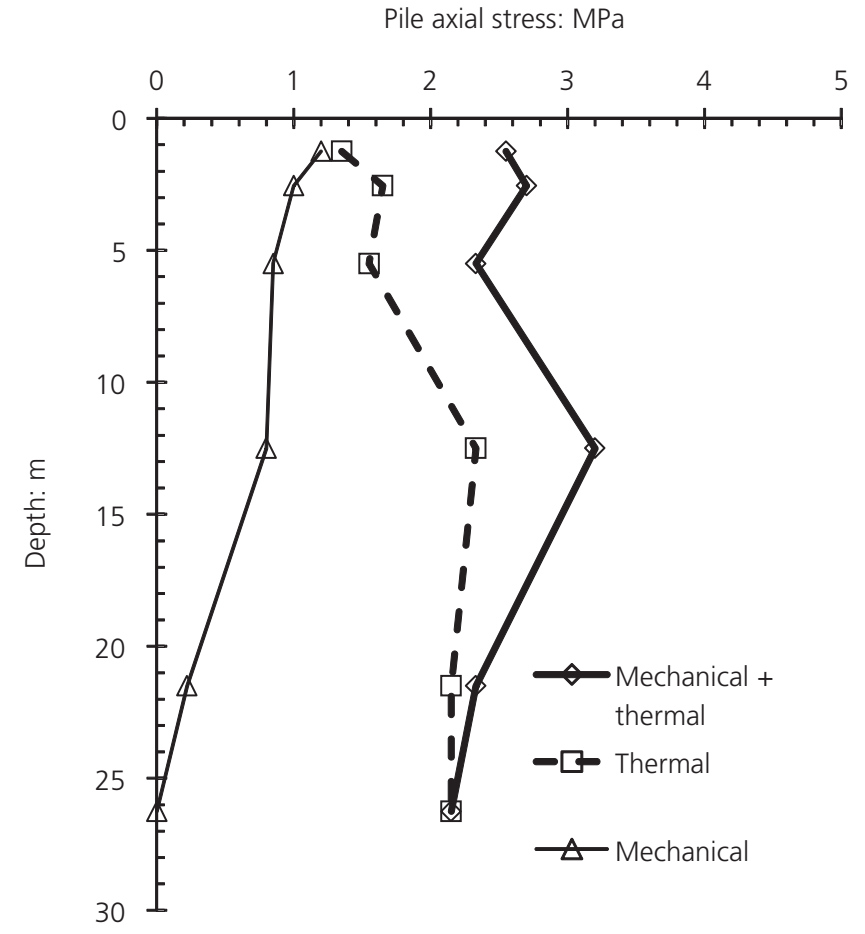

Figure 15. Load distribution in Lausanne test pile (after Laloui et al., 2006)

Finally, it is worth mentioning that recently in the UK the Ground Source Heat Pump Association produced the first standards for thermal pile design, installation and materials (GSHPA, 2012), where design charts for the energy pile were introduced based on a back analysis of a pile test in London Clay at Lambeth College. These charts should therefore be used with caution in other geological conditions. In fact, some of the above-mentioned concerns regarding the current energy pile design assumptions were also highlighted in this standard as areas where urgent research is needed. Therefore, it must be admitted that the current stage of knowledge in the energy pile design field is not yet complete and should be carefully considered within the context of its several limitations. As is the case with any research topic, the process of posing and answering particular research questions typically generates more questions that need to be explored through further research. The pioneer work done by Knellwolf et al. (2011), Amatya et al. (2012) and BourneWebb et al. (2012) raised some serious questions regarding the validity of the series of simplifications/assumptions that was used to interpret and predict the energy pile behaviour under coupled thermo-mechanical loading. Therefore, there is an urgent need for further research to be carried out to investigate thoroughly the temperature effects on pile-soil interaction.

\section{Energy pile heat exchanger function}

The heat exchange capacity of the energy pile depends on the thermal resistivity of the pile and the surrounding soils. The 


\begin{tabular}{lc}
\hline Mineral & Thermal conductivity: W/m. ${ }^{\circ} \mathrm{C}$ \\
\hline Quartz & $7 \cdot 8$ \\
Calcite & $3 \cdot 4$ \\
Dolomite & $5 \cdot 1$ \\
Anhydrite & $6 \cdot 4$ \\
Pyrite & $19 \cdot 2$ \\
Siderite & $3 \cdot 0$ \\
Orthoclase & $2 \cdot 3$ \\
Albite & $2 \cdot 3$ \\
Halite & $6 \cdot 5$ \\
Mica & $2 \cdot 3$ \\
Chlorite & $5 \cdot 1$ \\
Kaolinite & $2 \cdot 8$ \\
Smectite & $1 \cdot 8$ \\
Illite & $1 \cdot 8$ \\
Air & $0 \cdot 03$ \\
Water & $0 \cdot 60$
\end{tabular}

Table 1. Thermal conductivity of common minerals (Horai, 1971)

thermal resistance of the pile is usually assessed based on methods developed for borehole heat exchangers (Lamarche et al., 2010). However, this should be carefully considered as piles have a much smaller aspect ratio (length to diameter) than boreholes, and consequently, their thermal behaviour could be different. The pile thermal resistance calculated from in situ tests (Gao et al., 2008; Lennon et al., 2009; Wood et al., 2010) is not in good agreement with the theoretically calculated value. A comprehensive review of this aspect has been carried out by Loveridge and Powrie (2013). Other factors, such as the existence of ground water flow, geometrical configuration of the heat exchange pipes in the pile and pile layout, can also affect the performance of the heat exchanger function of the energy pile. More research work is required in this area.

The heat exchange capacity of an energy pile could be determined from an in situ test (thermal response test) or from an advanced three-dimensional numerical analysis (Ozudogru et al., 2012). Morino and Oka (1994) conducted the first experimental study to assess the heat exchange behaviour of a steel pile equipped with two vertical tubes. Pahud et al. (1996) developed a simulation tool using numerical methods for designing heat exchanger piles with vertical U-tube pipes based on the TRNSYS environment. Later, a heat exchanger pile system was designed using this simulation tool for heating and cooling a terminal building at Zurich Airport (Pahud et al., 1999).

Abdelaziz et al. (2011) list the possible mechanisms of heat transfer between the fluid circulated in a U-tube pipe of an energy pile and the ground as follows:
Model no.

1

Reference

Parallel heat flow (Voigt, 1910)

Series heat flow (Reuss, 1929)

Russel (1935)

Maxwell (1954)

Hashin and Shtrikman (1962)

$$
\lambda_{\mathrm{TU}}=\lambda_{\mathrm{s}}+\frac{n}{\frac{1}{\lambda_{\mathrm{f}}-\lambda_{\mathrm{s}}}+\frac{1-n}{3 \lambda_{\mathrm{s}}}} \quad \lambda_{\mathrm{TL}}=\lambda_{\mathrm{f}}+\frac{1-n}{\frac{1}{\lambda_{\mathrm{s}}-\lambda_{\mathrm{f}}}+\frac{n}{3 \lambda_{\mathrm{f}}}}
$$

$\lambda_{\mathrm{TL}}$ and $\lambda_{\mathrm{T}}$ are the lower and upper bounds respectively.

$$
\lambda_{\mathrm{T}}=\lambda_{\mathrm{s}}^{(1-n)}\left(\lambda_{\mathrm{f}}\right)^{n}
$$

Geometric mean method (Côté and Konrad, 2005b; McGaw, 1969)

Nimick and Leith (1992)

$$
\lambda_{\mathrm{T}}=\lambda_{\mathrm{TL}}\left[1-\frac{3 n(1-A)}{2+A+n(1-A)}\right] \quad A=\frac{\lambda_{\mathrm{TU}}}{\lambda_{\mathrm{TL}}}
$$

$\lambda_{\mathrm{TL}}$ and $\lambda_{\mathrm{TU}}$ from the model of Hashin and Shtrikman (1962)

$$
\frac{1}{\lambda_{\mathrm{T}}}=\frac{\beta-1}{\lambda_{\mathrm{f}} \beta}+\frac{\beta}{\lambda_{\mathrm{f}}\left(\beta^{2}-1\right)+\lambda_{\mathrm{s}}} \quad \beta=\sqrt[3]{\frac{1}{1-n}}
$$

Tarnawski et al. (2000); Gori and Corasaniti (2004) 
(a) Heat convection between the circulating fluid and the inner surface of the pipe

(b) Heat conduction through the circulation pipe wall

(c) Heat conduction within the pile

(d) Heat conduction within the in-situ soil

(e) Heat convection via the ground water flow, if any.
Abdelaziz et al. (2011) conducted a numerical analysis to investigate the effect of soil type, flow conditions in the circulation tubes, pile diameter and the thermal properties of the pile on the heat exchange capacity of the energy pile. They concluded that the thermal conductivity of the in situ soil has a significant effect on the heat exchange capacity of the thermo-pile, whereas the

Model no.

Model equation

Reference

9

$$
\lambda_{\mathrm{T}}=\frac{n \lambda_{\mathrm{f}}+\sum_{i=1}^{N} k_{i} \phi_{i}\left(\lambda_{\mathrm{s}}\right)_{i}}{n+\sum_{i=1}^{N} k_{i} \phi_{i}}
$$

De Vries (1963)

$N$ : number of individual types of soil solid components; $k$ : soil particle shape factor

$$
\lambda_{T}=\lambda_{\mathrm{f}} \frac{1+a \cdot b \cdot \phi}{1-b \cdot \phi \cdot \psi} \quad b=\frac{\left(\lambda_{\mathrm{s}} / \lambda_{\mathrm{f}}\right)-1}{\left(\lambda_{\mathrm{s}} / \lambda_{\mathrm{f}}\right)+a} \quad \psi=1+\left(\frac{1-\phi_{\mathrm{m}}}{\phi_{\mathrm{m}}{ }^{2}}\right) \cdot \phi
$$

Lewis and Nielsen (1970); Kumlutas et al. (2003)

$a$ and $\phi_{\mathrm{m}}$ are fabric parameters and maximum volumetric fraction of solid particles respectively.

$$
\lambda_{T}=\lambda_{f}\left\{\begin{array}{l}
1-\gamma_{a}^{2}-2 \gamma_{a} \gamma_{c}+2 \gamma_{a}^{2} \gamma_{c}+\frac{\gamma_{c}^{2} \gamma_{a}^{2}}{1 /\left(\frac{\lambda_{s}}{\lambda_{f}}\right)}+\frac{\gamma_{a}^{2}-\gamma_{a}^{2} \gamma_{c}^{2}}{1-\gamma_{a}+\gamma_{a} /\left(\frac{\lambda_{s}}{\lambda_{f}}\right)} \\
+\frac{2\left(\gamma_{a} \gamma_{c}-\gamma_{a}^{2} \gamma_{c}\right)}{1-\gamma_{a} \gamma_{c}+\left[\gamma_{a} \gamma_{c} /\left(\frac{\lambda_{s}}{\lambda_{f}}\right)\right]}
\end{array}\right\}
$$

Hsu et al. (1995)

where $n=\left(1-3 \gamma_{c}^{2}\right) \gamma_{a}^{3}+3 \gamma_{c}^{2} \gamma_{a}^{2} \quad\left(\frac{\lambda_{s}}{\lambda_{f}}\right)$

$\gamma_{\mathrm{a}}$ and $\gamma_{\mathrm{c}}$ are from fabric parameters related to the particle geometry and the particle contact respectively.

12

$$
\begin{aligned}
& \lambda_{\mathrm{T}}=\lambda_{\mathrm{f}} \frac{A_{\mathrm{nt}}}{A}\left\langle(1-\sqrt{1-\phi})+\frac{\sqrt{1-\phi}}{1+\left\{\left[1 /\left(\frac{\lambda_{\mathrm{s}}}{\lambda_{\mathrm{f}}}\right)\right]-1\right\} \sqrt{1-\phi}}\right\rangle+\left(1-\frac{A_{\mathrm{nt}}}{A}\right) \\
& \times \frac{\lambda_{\text {p.max }}^{2}}{A}\left(\frac{\lambda_{\text {p.max }}}{L_{0}}\right)^{D_{T}-1} \frac{D_{f}}{1+D_{\mathrm{T}}-D_{\mathrm{f}}}\left(\frac{1}{\gamma_{\mathrm{a} 1} /\left(\frac{\lambda_{\mathrm{s}}}{\lambda_{\mathrm{f}}}\right)+\frac{\left(1-\gamma_{\mathrm{a} 1}\right)}{\left\{\gamma_{\mathrm{c} 1}^{2}\left[\left(\frac{\lambda_{\mathrm{s}}}{\lambda_{\mathrm{f}}}\right)-1\right] / \gamma_{\mathrm{a} 1}^{2}\right\}+1}}\right)
\end{aligned}
$$

where $\frac{A_{\mathrm{nt}}}{A}, \gamma_{\mathrm{a} 1}, \gamma_{\mathrm{c}}, \lambda_{\mathrm{p} \text {.max }}, L_{0}, D_{f}$, and $D_{\top}$ are fabric parameters that describe the particle contact and geometry and the fractal media.

$\lambda_{\mathrm{T}}, \lambda_{\mathrm{s}}$, and $\lambda_{\mathrm{f}}$ are the thermal conductivities of the soil, solid soil particles and soil pore water respectively. $n$ and $\phi$ are the soil porosity and volumetric fraction of solid particles $(\phi=1-n)$ respectively.

Table 3. Theoretical thermal conductivity mixture model (two-phase system) including soil particles fabric effect 


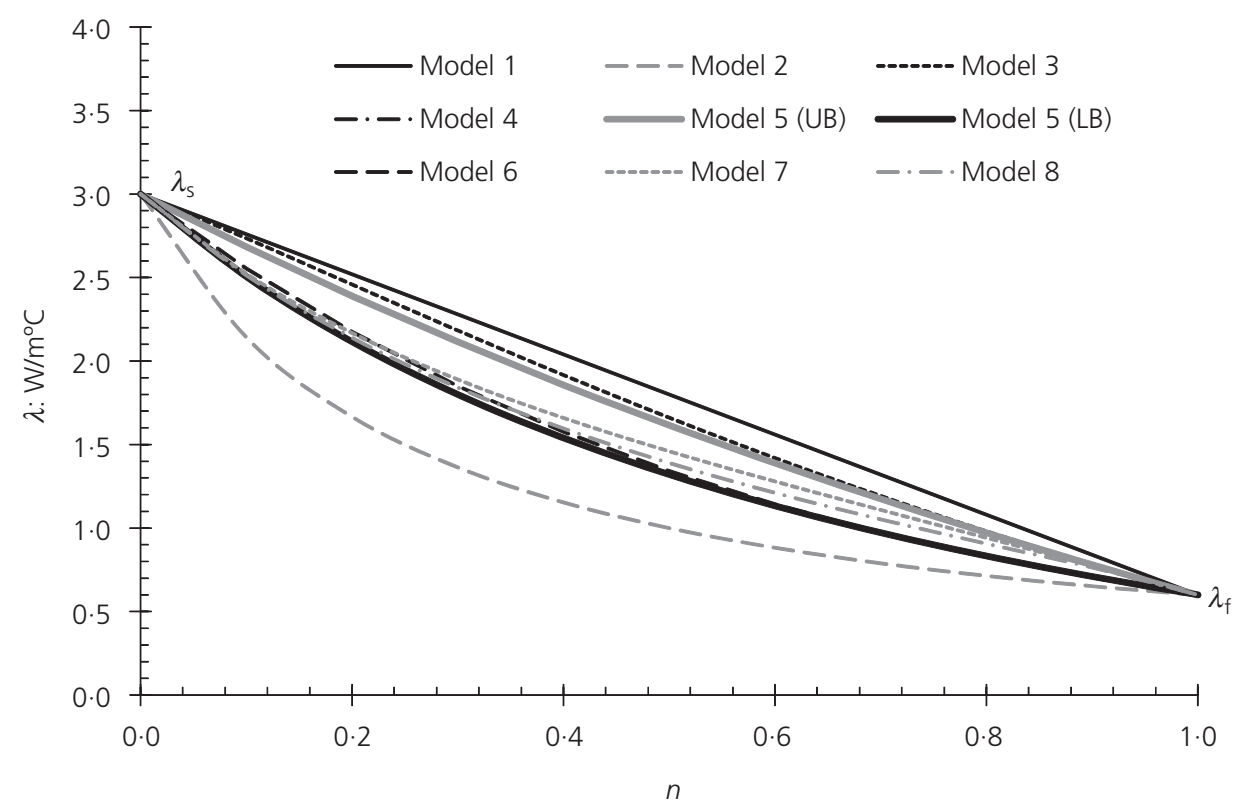

Figure 16. Behaviour of different theoretical thermal conductivity mixture models in $\lambda_{T}-n$ plane (assuming the thermal conductivity value of solids and water is 3.0 and $0.6 \mathrm{~W} / \mathrm{m}^{\circ} \mathrm{C}$ respectively)

thermal conductivity of the pile material had a modest effect on the heat exchange capacity. Their study also indicated that the diameter of the circulation pipe had an insignificant effect. In the following section, the current state of knowledge in the field of heat transport properties of soils and the factors that control them will be reviewed.

\section{Heat transfer properties of soils}

Heat transfer through geomaterials is of great interest in many geoengineering projects involving thermal effects, such as oil and gas pipelines (Slegel and Davis, 1977), buried high voltage electrical cables (Abdel-Hadi and Mitchell, 1981), ground heat energy storage (Moritz, 1995), heat exchanger piles (Laloui and Cekerevac, 2003), clay barriers for nuclear waste repositories (Gera et al., 1996) and ground improvement using thermal stabilisation (Abuel-Naga et al., 2006b). In general, thermal energy can be transported through geomaterials by conduction, radiation and convection processes. Conduction of heat in soils occurs by transmission of the thermal energy from one particle to another. Convection is the transport of heat by a heat-carrying mass. Radiation is the transfer of the thermal energy by electromagnetic waves. Both convection and conduction of heat require molecules to transfer the heat, whereas radiation heat transfer does not require molecules to transfer heat from one surface to another. For saturated clays, heat transfer by conduction is of primary importance, whereas heat transfer by convection is of secondary importance since the clay hydraulic conductivity is very small. Radiation heat transfer can only become significant in dry soils with large pores under high temperature difference ranges.
Efforts have been made by several researchers (Britto et al., 1992; Chen and Liu, 2006; Thomas and Li, 1997) to model the heat transfer through geomaterials with the help of analytical or numerical models, with particular attention given to the estimation of the soil thermo-physical properties that control the magnitude and rate of heat flow. The main soil thermo-physical properties are the thermal conductivity $\left(\lambda_{\mathrm{T}}\right)$, the thermal diffusivity $(D)$ and the heat capacity $(C)$. The relationship between the three properties is given as follows:

\section{2. $D=\lambda_{\mathrm{T}} / C$}

Many researchers have used the fact that the heat capacity of a given soil is the sum of the heat capacities of the soil constituents to estimate $C$ (De Vries and Afgan, 1975). By estimating $C$ and measuring $\lambda_{\mathrm{T}}$, the remaining thermal property $D$ can be determined using Equation 2. Field or laboratory tests can be used to measure the thermal conductivity of soils. However, the field tests are expensive and time consuming and have no freedom to control the boundary conditions. On the other hand, laboratory tests are relatively inexpensive and simple to conduct. However, great care should be given to the soil disturbance and the fitting of the governing equation to the boundary conditions of the test apparatus.

Several researchers (Abu-Hamdeh et al., 2000; Brandon and Mitchell, 1989; Côté and Konrad, 2005a; Farouki, 1981; Morin and Silva, 1984; Ochsner et al., 2001; Sepaskhah and Boersma, 
1979) have shown that the thermal conductivity is related to soil properties, such as mineralogy composition, dry density (porosity), pore fluid, degree of saturation, water content and temperature. Table 1 lists the thermal conductivity of common minerals. The effect of the geometrical arrangement of soil particles on the thermal conductivity value of saturated clays has also been discussed by Penner (1963), Mitchell (1993) and Midttømme et al. (1998).

\section{Predicting thermal conductivity of saturated soils}

Saturated soil can be considered as a two-phase composite material. Numerous theoretical and empirical approaches have been developed to predict the evolution of the thermal conductivity of a two-phase composite material as a function of the thermal conductivity and the volumetric proportions of the different phases as well as their texture (fabric) within the medium. The use of theoretical-based models is recommended as the validity of the empirical equations is always limited to specific conditions. Tables 2 and 3 include some of the theoretical mixture models that have been developed to simulate the thermal conductivity of two-phase systems. The models listed in Table 2 were derived without taking into consideration the fabric configuration effects on the thermal conductivity. Figure 16 shows the behaviour of these models in the thermal conductivity-porosity $\lambda_{\mathrm{T}}-n$ plane, where $\lambda_{\mathrm{T}}$ and $n$ are the thermal conductivity and porosity of the soil respectively. The parallel and series heat flow modes (Models 1 and 2) can be considered as the upper and lower bounds of the theoretical models, as shown in Figure 16.

On the other hand, the models listed in Table 3 are flexible in terms of considering different fabric conditions since they include fabric parameters. However, they also have some limitations. According to Johansen (1975), the values of the shape factors used by De Vries (1963) were empirical since they can hardly represent the geometrical shape of sand particles. Kumlutas et al. (2003) show that the Lewis and Nielsen (1970) model underpredicts the thermal conductivity. The model proposed by Hsu et al. (1995) linked its fabric parameters to the soil porosity (Ma et al., 2003). Finally, the large number of parameters in the Yu and Cheng (2001) model hindered its applicability. Based on the above discussion, it can be concluded that a simple thermal conductivity model that can overcome the limitations of the available models is still required.

\section{Conclusions}

As energy piles are subjected to coupled mechanical and thermal load, their design must consider the temperature change effects on the pile and its surrounding soils. This review paper has discussed the thermo-hydro-mechanical behaviour of saturated clays and the thermal conductivity of the soil, as these have a significant effect on the heat exchange capacity of the energy pile. Moreover, a conceptual understanding of the potential effect of temperature change on the pile-soil interaction was suggested. The available energy pile design methods in the literature were critically reviewed by questioning the validity of their assumptions in light of the current state of knowledge in the field of thermo-hydro-mechanical behaviour of saturated clays. In conclusion, further research work is still required to thoroughly investigate the temperature effects on pile-soil interaction as it could help in assessing the validity of the assumptions of the available energy pile design methods in the literature.

\section{REFERENCES}

Abdelaziz SL, Olgun CG and Martin JR (2011) Design and operational considerations of geothermal energy piles. In Proceedings of Geo-Frontiers 2011: Advances in Geotechnical Engineering (Han J and Alzamora DE (eds)). ASCE Geotechnical Special Publication No. 211, pp. 450-459. Abdel-Hadi ON and Mitchell JK (1981) Coupled heat and water flows around buried cables. Journal of the Geotechnical Engineering Division, ASCE 107(11): 1461-1487.

Abuel-Naga HM, Bergado DT, Grino L, Rujivipat $P$ and Thet $Y$ (2006a) Experimental evaluation of engineering behavior of soft bangkok clay under elevated temperature. Journal of Geotechnical and Geoenvironmental Engineering, ASCE 132(7): 902-910.

Abuel-Naga HM, Bergado DT and Chaiprakaikeow S (2006b) Innovative thermal technique for enhancing the performance of prefabricated vertical drain system. Geotextiles and Geomembranes 24(6): 359-370.

Abuel-Naga HM, Bergado DT and Lim BF (2007a) Effect of temperature on shear strength and yielding behavior of soft Bangkok clay. Soils and Foundations 47(3): 423-436.

Abuel-Naga HM, Bergado DT and Bouazza A (2007b) Thermally induced volume change and excess pore water pressure of soft Bangkok clay. Engineering Geology 89(1-2): 144-154.

Abuel-Naga HM, Bergado DT, Bouazza A and Ramana GV (2007c) Volume change behavior of saturated clays under drained heating conditions: experimental results and constitutive modeling. Canadian Geotechnical Journal 44: 942-956.

Abuel-Naga HM, Bergado DT, Bouazza A and Pender MJ (2009) Thermomechanical model for saturated clays. Geotechnique 59(3): 273-278.

Abu-Hamdeh NH and Reeder RC (2000) Soil thermal conductivity: effects of density, moisture, salt concentration, and organic matter. Soil Science Society of America Journal 64: $1285-1290$.

Amatya BL, Soga K, Bourne-Webb P, Amis T and Laloui L (2012) Thermo-mechanical behaviour of energy piles. Géotechnique 62(6): 503-519.

Amis T, Bourne-Webb P, Davidson C, Amatya B and Soga K (2008) The effects of heating and cooling energy piles under working load at Lambeth College, UK. Proceedings of the 33rd Annual and 11th International Conference of the Deep Foundations Institute, New York, USA. Article \#1614, 10 pp.

Baldi G, Hueckel T and Pelegrini R (1988) Thermal volume changes of the mineral-water system in low-porosity clay soils. Canadian Geotechnical Journal 25: 807-825. 


\section{Offprint provided courtesy of www.icevirtuallibrary.com Author copy for personal use, not for distribution}

Boënnec O (2009) Piling on the Energy. Geodrilling International (150): 25-28.

Boudali M, Leroueil S and Srinivasa MBR (1994) Viscous behaviour of natural clays. Proceedings of 13th International Conference on Soil Mechanics and Foundation Engineering, New Delhi, India. pp. 411-416.

Bourne-Webb P, Amatya B and Soga K (2009) Energy pile test at Lambeth College, London: geotechnical and thermodynamic aspects of pile response to heat cycles. Géotechnique 59(3): $237-248$

Bourne-Webb PJ, Amatya BL and Soga K (2012) A framework for understanding energy pile behaviour. Proceedings of the ICE - Geotechnical Engineering, http://dx.doi.org/10.1680/ geng.10.00098.

Brandl H (1998) Energy piles and diaphragm walls for heat transfer from and into the ground. Proceedings of the 3rd International Geotechnical Seminar, Deep Foundations on Bored and Auger Piles (BAP III), University of Ghent, Ghent, Belgium, vol. 1, pp. 37-60.

Brandl H (2006) Energy foundations and other thermo-active ground structures. Géotechnique 56(2): 81-122.

Brandon TL and Mitchell JK (1989) Factors influencing the thermal resistivity of sands. Journal of the Geotechnical Engineering Division, ASCE 115: 1683-1698.

Britto AM, Savvidou C, Gunn MJ and Booker JR (1992) Finite element analysis of the coupled heat flow and consolidation around hot buried objects. Soils and Foundations 32(1): 13-25.

Burghignoli A, Desideri A and Miliziano S (2000) A laboratory study on the thermomechanical behaviour of clayey soils. Canadian Geotechnical Journal 37: 764-780.

Campanella RG and Mitchell JK (1968) Influence of temperature variations on soil behavior. Journal of the Soil Mechanics and Foundations Division, ASCE 94: 709-734.

Cekerevac C (2003) Thermal Effects on the Mechanical Behavior of Saturated Clay. Doctoral Thesis No. 2828, Swiss Federal Institute of Technology, Lausanne, Switzerland.

Cekerevac C and Laloui L (2004) Experimental study of thermal effects on the mechanical behaviour of a clay. International Journal for Numerical and Analytical Methods in Geomechanics 28: 209-228.

Chen W and Liu W (2006) Numerical and experimental analysis of heat and moisture content transfer in a lean-to greenhouse. Energy and Buildings 38(2): 99-104.

Côté J and Konrad J-M (2005a) Thermal conductivity of basecourse materials. Canadian Geotechnical Journal 42(1): 61-78.

Côté J and Konrad J-M (2005b) A generalized thermal conductivity model for soils and construction materials. Canadian Geotechnical Journal 42: 443-458.

Coyle HM and Reese LC (1966) Load transfer for axially loadedpiles in clay. Journal of the Soil Mechanics and Foundations Division 92(2): 1-26.

De Vries DA (1963) Thermal properties of soils. In Physics of Plant Environment (Van Wijk WR (ed)). North-Holland Publishing Company, Amsterdam, The Netherlands, pp. 210-235.

De Vries DA and Afgan NH (1975) Heat and Mass Transfer in the Biosphere. Scripta Book, Washington.
Del Olmo C, Fioravante V, Gera F et al. (1996) Thermomechanical properties of deep argillaceous formations. Engineering Geology 41: 87-102.

Delage P, Sultan N and Cui YJ (2000) On the thermal consolidation of Boom clay. Canadian Geotechnical Journal 37: 343-354.

Ennigkeit A and Katzenbach R (2001) The double use of piles as foundation and heat exchanging elements. Proceedings of the 15th International Conference on Soil Mechanics and Geotechnical Engineering, Istanbul. CRC Press/A A Balkema, pp. 893-896.

Eriksson LG (1989) Temperature effects on consolidation properties of sulphide clays. Proceedings of 12th International Conference on Soil Mechanics and Foundation Engineering, Rio de Janeiro. Taylor and Francis, London, UK, pp. 2087-2090.

Farouki OT (1981) Thermal Properties of Soils. US Army Corps of Engineers, Cold Regions Research and Engineering Laboratory, Hanover, N.H. CRREL Monograph $81-1$.

Gao J, Zhang X, Liu J, Li K and Yang J (2008) Numerical and experimental assessment of thermal performance of vertical energy piles: an application. Applied Energy 85(10): 901-910.

Gera F, Hueckel T and Peano A (1996) Critical issues in modelling of the long-term hydro-thermal performance of natural clay barriers. Engineering Geology 41: 17-33.

Gori F and Corasaniti S (2004) Theoretical prediction of the thermal conductivity and temperature variation inside Mars soil analogues. Planetary and Space Science 52: 91-99.

Graham J, Tanaka N, Crilly T and Alfaro M (2001) Modified Cam-Clay modeling of temperature effects in clays. Canadian Geotechnical Journal 38(3): 608-621.

GSHPA (2012) Thermal Pile Design, Installation and Materials Standards, Ground Source Heat Pump Association, http:// www.gshp.org.uk/GSHPA_Thermal_Pile_Standard.html.

Habibagahi K (1977) Temperature effect and the concept of effective void ratio. Indian Geotechnical Journal 7(1): 14-34.

Hashin Z and Shtrikman S (1962) A variational approach to the theory of the effective magnetic permeability of multi-phase materials. Journal of Applied Physics 33(10): 3125-3131.

Houston SL, Houston WN and Williams ND (1985) Thermomechanical behavior of seafloor sediments. Journal of Soil Mechanics and Foundation Division, ASCE 111: 1249-1263.

Houston SL and Lin HD (1987) A thermal consolidation model for pelagic clays. Marine Geotechnology 7: 79-98.

Hsu CT, Cheng P and Wong KW (1995) A lumped-parameter model for stagnant thermal conductivity of spatially periodic porous media. Journal of Heat Transfer 117: 264-269.

Hueckel T and Baldi M (1990) Thermoplastic of saturated clays: an experimental constitutive study. Journal of Geotechnical Engineering, ASCE 116: 1778-1796.

Hueckel T and Pellegrini R (1992) Effective stress and water pressure in saturated clays during heating-cooling cycles. Canadian Geotechnical Journal 29: 1095-1102. 
Johansen O (1975) Thermal Conductivity of Soils. PhD thesis, University of Trondheim, Trondheim, Norway.

Knellwolf C, Peron H and Laloui L (2011) Geotechnical analysis of heat exchanger piles. Journal of Geotechnical and Geoenvironmental Engineering 137(10): 890-902.

Kumlutas D, Tavman IH and Coban MT (2003) Thermal conductivity of particle filled polyethylene composite materials. Composite Science and Technology 63: 113-117.

Kuntiwattanakul P, Towhata I, Ohishi K and Seko I (1995) Temperature effects on undrained shear characteristics of clay. Soils Foundations 35(1): 147-162.

Laloui L and Cekerevac C (2003) Thermo-plasticity of clays: an isotropic yield mechanism. Computer and Geotechnics 30: 649-660.

Laloui L, Nuth M and Vulliet L (2006) Experimental and numerical investigations of the behaviour of a heat exchanger pile. International Journal for Numerical and Analytical Methods in Geomechanics 30(8): 763-781.

Lamarche L, Kajl S and Beauchamp B (2010) A review of methods to evaluate borehole thermal resistances in geothermal heatpump systems. Geothermics 39(2): 187-200.

Lennon DJ, Watt E and Suckling TP (2009) Energy piles in Scotland. In Proceedings of the 5th International Conference on Deep Foundations on Bored and Auger Piles, Frankfurt (Van Impe WF and Van Impe PO (eds)). Taylor and Francis, London, UK, pp. 349-356.

Lewis T and Nielsen L (1970) Dynamic mechanical properties of particulate-filled polymers. Journal of Applied Polymer Science 14(6): 1449-1471.

Loveridge F and Powrie W (2013) Pile heat exchangers: thermal behaviour and interactions. Proceedings of the Institution of Civil Engineers Geotechnical Engineering 166(2): 178-196.

Ma YT, Yu BM, Zhang DM, and Zou MQ (2003) A self-similarity model for effective thermal conductivity of porous media. Journal of Physics D: Applied Physics 36: 2157-2164.

Maxwell JC (1954) A Treatise on Electricity and Magnetism, 3rd edn. Dover, New York.

McGaw R (1969) Heat conduction in saturated granular materials. Highway Research Board, Special Report 103: 144-131.

Midttømme K, Roaldset E and Aagaard P (1998) Thermal conductivity of selected claystones and mudstones from England. Clay Minerals 33: 131-145.

Mitchell JK (1993) Fundamental of Soil Behavior. John Wiley \& Sons, Inc., New York.

Morin R and Silva AJ (1984) The effect of high pressure and high temperature on some physical properties of ocean sediments. Journal of Geophysical Research 89(B1): 511-526.

Morino K and Oka T (1994) Study on heat exchanged in soil by circulating water in a steel pile. Energy and Buildings 21(1): 65-78.

Moritz L (1995) Geotechnical properties of clay at elevated temperatures. International Symposium on Compression and Consolidation of Clayey Soils, IS-Hiroshima, Japan. A.A Balkema, pp. 267-272.

Nimick FB and Leith JR (1992) A model for thermal conductivity of granular Porous media. Journal of Heat Transfer 114: 505-508.
Ochsner TE, Horton R and Ren T (2001) A new perspective on soil thermal properties. Soil Science Society of America Journal 65: $1641-1647$.

Ozudogru T, Brettmann T, Guney Olgun C, Martin II J and Senol A (2012) Thermal conductivity testing of energy piles: field testing and numerical modeling. GeoCongress 2012. American Society of Civil Engineers, pp. 4436-4445.

Pahud D, Fromentin A and Hadorn JC (1996) The duct ground heat storage model (DST) for TRNSYS used for the simulation of heat exchanger piles. User Manual, December 1996 version, Internal Report, LASEN-DGC-EPFL, Switzerland.

Pahud D, Fromentin A and Hubbuch M (1999) Heat exchanger pile system for heating and cooling at Zurich Airport. IEA Heat Pump Centre Newsletter 17(1): 15-16.

Penner E (1963) Anisotropic thermal conduction in clay sediments. Proceedings of International Clay Conference, Stockholm, Pergamon Press, New York, pp. 365-376.

Phetteplace G (2007) Geothermal heat pumps. Journal of Energy Engineering 133(1): 32-38.

Reuss A (1929) Berechnung der Fliel3grenze von Mischkristallen auf Grund der Plastizititsbedingung f'tir Einkristalle.

Zeitschrift für Angewandte Mathematik and Mechanik 9: 49-58.

Robinet JC, Rahbaou A, Plas F and Lebon P (1996) A constitutive thermomechanical model for saturated clays. Engineering Geology 41: 145-169.

Seed HB and Reese LC (1957) The action of soft clay along friction piles. Transactions of the American Society of Civil Engineers 122: 731-754.

Sepaskhah AR and Boersma L (1979) Thermal conductivity of soils as a function of temperature and water content. Soil Science Society of America Journal 43: 439-444.

Shoukry SN, William GW, Downie B and Riad MY (2011) Effect of moisture and temperature on the mechanical properties of concrete. Construction and Building Materials 25(2): 688-696.

Slegel DL and Davis LR (1977) Transient heat and mass transfer in soils in the vicinity of heated porous pipes. Journal of Heat Transfer 99: 541-621.

Sultan N, Delage P and Cui YJ (2002) Temperature effects on the volume change behavior of Boom clay. Engineering Geology 64: $135-145$.

Tarnawski VR, Gori F, Wagner B and Buchan GD (2000) Modeling approaches to predicting thermal conductivity of soils at high temperatures. International Journal of Energy Research 24: 403-423.

Tanaka N, Graham J and Crilly TN (1997) Stress-strain behaviour of reconstituted illitic clay at different temperatures. Engineering Geology 47: 339-350.

Tavenas F, Jean P, Leblond P and Leroueil S (1983) The permeability of natural soft clays. Part II: Permeability characteristics. Canadian Geotechnical Journal 20: 645-660.

Thomas HR and Li CLW (1997) Modelling heat and moisture transfer in unsaturated soil using a finite difference selfimplicit method on parallel computers. International Journal for Numerical and Analytical Methods in Geomechanics 21(6): 409-419. 
Towhata I, Kuntiwattanakul P, Seko I and Ohishi K (1993) Volume change of clays induced by heating as observed in consolidation tests. Soils Foundations 334: 170-183.

Voigt W (1910) Lehrbuch der Kristallphysik, 1st edn. Teubner, Leipzig.

Wood CJ, Liu H and Riffat SB (2010) Comparison of a modelled and field tested piled ground heat exchanger system for a residential building and the simulated effect of assisted ground heat recharge. International Journal of Low Carbon Technologies 5(12): 137-143.

Yu BM and Cheng P (2001) Fractal models for the effective thermal conductivity of bi-dispersed porous media. Journal of Thermophysics and Heat Transfer 16: 22-29.

\section{WHAT DO YOU THINK?}

To discuss this paper, please submit up to 500 words to the editor at journals@ice.org.uk. Your contribution will be forwarded to the author(s) for a reply and, if considered appropriate by the editorial panel, will be published as a discussion in a future issue of the journal. 